\title{
Narcissism and Oedipus Complex in Adolescence: Based on Choi In-Hun's Novel 'The Square'
}

\author{
Jae Yong Jang ${ }^{1}$ and Jee Hyun $\mathrm{Ha}^{2}$ \\ ${ }^{1}$ Department of Psychiatry, Yongin Mental Hospital, Yongin, Korea \\ ${ }^{2}$ Deparment of Psychiatry, School of Medicine, Konkuk University, Seoul, Korea
}

\section{청소년기 자기애와 오이디푸스 갈등: 최인훈의 '광장'}

장재용 ${ }^{1}$ 하지현 ${ }^{2}$

${ }^{1}$ 용인정신병원 정신건강의학과, ${ }^{2}$ 건국대학교 의학전문대학원 정신건강의학교실

\begin{abstract}
Adolescence is a period of finding one's position through separation and individualization from parents during physical and psychological changes, and it is a period of establishing one's identity, searching for a job, experiencing peer friendship, and deep intimacy with the opposite sex. At this time, there may be a narcissistic reaction to maintain and develop self-esteem, which has been lowered by experiencing the process of separation-individuation from parents. In adolescence, an egocentric tendency to harbor omnipotence, uniqueness, and indestructibility can be prominent. To form a healthy and normal identity and enter adulthood, addressing narcissism and the revisited Oedipus complex is an important psychological task in adolescence. Formation of the superego and ego ideal through competition and conflict with same-sex parents can facilitate the balanced development of narcissism. Additionally, the formation of intimacy with the opposite sex facilitated in reprocessing the Oedipal drive toward the opposite-sex parent and to overcome difficulties in one's development.

Psychoanalysis 2022;33(1):19-30
\end{abstract}

Keywords: Oedipus complex; Young adult; Adolescent development; Narcissism.

Received: November 23, 2021 Revised: December 13, 2021 Accepted: December 19, 2021

Address for correspondence: Jee Hyun $\mathrm{Ha}, \mathrm{MD}$

Deparment of Psychiatry, School of Medicine, Konkuk University,120 Neudong-ro, Gwangjin-gu, Seoul 05029, Korea

Tel: +82-2-2030-7569, Fax: +82-2-2030-7748, E-mail: jhnha@naver.com

\section{서 론}

청소년기는 국어사전에 의하면 청년과 소년을 함께 가리키 며 특히 10 대의 남녀를 가리키는 말로 정의한다. 정신발달학 적인 관점에서 청소년기란 사춘기가 진행되며 오는 신체적, 심리적 변화와 함께 정신적 조직화가 가능해지는 시기다. 이 시기에 청소년은 자기와 다른 사람과의 관계에서 일어나는 변화들을 통합하는 능력을 발전시키게 된다(Erikson 1956).

약 200년 전인 18세기 후반, 영국을 중심으로 일어난 산업 혁명 이후 사람들의 삶터는 농사를 짓는 시골이 아닌 공장 이 있는 도시가 되기 시작했다. 도시에 살게 된 사람들은 글 을 배우고 셈을 할 줄 아는 능력이 필요했고 시민의 매너, 상

This is an Open Access article distributed under the terms of the Creative Commons Attribution Non-Commercial License (https://creativecommons.org/licenses/by-nc/4.0) which permits unrestricted non-commercial use, distribution, and reproduction in any medium, provided the original work is properly cited.
식, 법률, 가치관 등도 익혀야 했다. 어른이 되기 전, 사회에 적응하고 일을 하기 위해 학교에서 교육을 받을 시간이 필 요해지며 청소년기를 규정할 필요가 생겼다(Ha 2017). 이 시기의 심리발달은 소아기에 해결되지 않는 것들이 재활성 화되기 때문에 성인기의 정상적이고 건강한 삶을 위해 이 시기의 발달과제를 잘 해결하고 성취하는 것이 중요하다.

청소년기의 시작인 사춘기가 진행됨에 따라 소녀는 초경 을 시작하게 되며, 소년은 몽정을 하게 된다. 청소년은 예측 불허한 키와 몸무게의 성장을 경험하며 당황하기도 하지만, 이러한 변화를 수용하고 통합해 가면서 몸을 통한 자부심과 기쁨을 느끼기도 한다. 청소년은 부모로부터 멀어지고자 또 래 관계 형성에 집중하며 이성의 관심을 끌고자 외모와 옷, 머리 스타일 등에 신경쓰기 시작한다. 또한 청소년은 자신의 정체성에 대한 의문과 함께 성인기를 대비하기 위한 자신의 직업을 탐색하기 시작한다(Colarusso 1992).

인지적, 심리적 발달과 함께 어른의 신체를 갖게 된 청소 
년은 부모가 더는 이상적인 대상이 아님을 인식하고 탈이상 화와 개별화를 시작한다. Blos (1967)는 이를 2차 분리-개별 화 과정(second separation-individualization)이라 불렀으며 부모와의 분리를 통해 청소년은 독립적인 존재로서 정신구 조를 재조직화 하고 자신만의 정체성을 발달시킬 수 있다고 보았다. 하지만 걸음마기에 일차 개별화 과정을 통과하기 위 해서는 부모의 존재가 계속 필요했던 것과 마찬가지로, 청소 년도 앞에서 언급한 발달 과제를 안전하게 달성하기 위해서 는 부모와의 규칙적 접촉이 필요하다. 부모의 역할은 지속적 돌봄은 물론 성숙한 판단과 제한 설정 연습의 복합체로 작 용한다(Colarusso 1992).

이 시기에 청소년은 부모와 심리적으로 분리되면서 공허 감과 빈곤감, 상실에 대한 애도감을 느끼게 된다. 청소년은 부모와 분리로 인해 경험되는 자기 취약성을 방어하고 대처 하기 위한 일환으로 자기애적 측면이 두드러지게 나타날 수 있다(Blos 1962). Elkind (1967)는 이 시기에 보이는 자기애 의 특성으로 무엇이든 다 해낼 수 있을 것이라는 전능감 (omnipotence), 그 누구와 비교할 수 없는 자기만의 독특한 존재감(uniqueness), 절대 파괴되거나 다치지 않을 것이라는 믿음(invulnerability 또는 indestructibility)을 열거했다.

이 시기의 이런 자기애의 강화는 병적인 측면보다 건강한 발달을 위해 필요한 면이 많다. 청소년기에 건강한 자기애의 발달은 복잡한 청소년기를 이행하는 과정에 경험하게 되는 고통을 이겨내는데 중요하다. 건강한 자존감의 형성은 독립 으로 인한 외로움과 거절의 고통을 완화시키고 안정적인 대 인관계를 형성할 초석이 된다. 또한 청소년이 성인기로 잘 넘어가도록 하는데 도움이 되는 유용한 기술과 능력 획득 및 승화과정을 촉진한다.

한편 Klein (1932)은 잠복기와 청소년기를 비교하면서, 청 소년들은 욕동의 움직임에 대하여 강력한 지배를 받는다는 점과 풍부한 환상적 활동을 한다는 점에서 오히려 잠복기 이전의 어린 아동과 유사성을 지닌다고 하였다. 이처럼 청소 년기에 일시적으로 초기 유아기 단계로의 전환이 일어나고 새로운 환경 위에서 생애 초기 발달 과정을 다시 한번 거치 게 된다(Jones 1923).

청소년기 호르몬에 의해 유도된 신체적, 성적 변화는 부모 와의 관계를 포함하여 모든 관계에 영향을 미친다. 잠복기 때는 수월하게 오이디푸스 갈등의 억제 상태를 유지할 수 있었으나, 신체적, 성적 성숙으로 실제 성행위가 가능함을 알게 된 청소년은 부모와 관련된 자신의 성적 공상이 실현 될 수 있다는 위험성을 무의식적 수준에서 위협받는다. 이러 한 불안 속에 청소년은 자신의 오이디푸스식 공상과 소망을 재처리할 필요성을 느끼게 된다(Colarusso 1992).
그래서 청소년기에는 잠복기 이전에 한 번 해결되었던 오 이디푸스 콤플렉스가 재활성화된다. 이 시기에 다시 활성화 된 오이디푸스 콤플렉스를 건강한 방식으로 해소하고 나면 현실감각을 갖게 되고, 부모와 이전과 질적으로 다른 관계를 두면서 자율성을 획득한다. 그리고 자아 이상의 동일시 대상 을 현실적 대상으로 변화시키거나, 현실의 대상들에게 만족 하면서 자연스럽게 성인기에 걸맞은 현실적 수준의 자기애 를 가질 수 있다. 초기 성인기에 만날 사회적 정체성을 형성 하는 과정에 생길 여러 가지 현실적 갈등이나 좌절을 견디 는데 건강한 자기애는 매우 중요하다.

반면 청소년기 오이디푸스 콤플렉스의 적절한 해소 과정 을 경험하지 못하면 현실적인 측면에서의 초자아와 자아 이 상의 수정과 발달이 이루어지지 않게 될 수 있다. 이후 자아 중심적인 자기애의 특성이 지속된 청소년은 현실의 대상에 대한 반복적인 기대와 실망 속에서 현실 적응에 어려움을 겪을 수 있다. 그리고 성인기에 이르러서도 청소년기의 비현 실적인 자기애를 유지하면서 대인관계, 사회적응에 어려움 이 생길 위험이 있다. 따라서 건강하고 정상적인 정체성 형 성과 성인기 진입을 하는데 자기애를 다루는 것, 이와 연관 한 재활성화된 오이디푸스 콤플렉스는 청소년기의 중요한 심 리적 과제로 다가온다.

저자들은 이런 청소년기의 자기애 문제를 최인훈의 소설 인 '광장'의 주인공 명준에서 발견하였다. 소설의 주인공인 명준은 1950년대 남과 북으로 나뉜 격변의 시기를 겪는 인 물이다. 청소년기 발달을 경험하는 명준의 모습에서 청소년 기의 자기애적 측면을 찾아볼 수 있었다. 또한 아버지와의 갈등을 경험하고, 어머니의 대리자인 은혜를 만나 친밀감을 형성하는 과정이 청소년기의 재활성화된 오이디푸스 콤플 렉스와 연관된 것으로 보일 부분이 많았다. 이후 아버지와의 오이디푸스 갈등을 적절히 해소하지 못하게 된 명준이 성인 기에 걸맞은 자기애를 형성하지 못하게 되며 현실 적응에 어려움을 겪는 것을 관찰할 수 있었다.

이에 저자들은 '광장'의 등장인물 명준의 심리와 행동변화 를 추적하면서 청소년기 자기애의 발달과 해소, 성인기로 진 입하는 과정에 청소년기에 대두되는 오이디푸스 갈등의 재 활성화가 서로 어떤 연관이 있는지 알아보려고 한다. 이를 건강하게 경험하고 해소하지 못하게 되면 어떤 문제가 발생 할 수 있는지 정신분석적 관점에서 해석하고자 한다.

\section{본 론}

\section{작가 최인훈(1936-2018 崔仁勳)}

'광장'의 작가인 최인훈은 1936년, 두만강 변의 국경 도시 
함경북도 회령에서 4남 2녀의 장남으로 출생했다. 그는 상업 에 종사한 아버지 덕분에 경제적으로 풍요로운 어린 시절을 보내며 가족들과 단란하고 평화로운 시절을 보냈다. 1943년 7세, 최인훈은 회령북초등학교에 입학하였는데, 도서관에 있는 일본어 서적을 읽으며 자연스럽게 독서 취미가 형성되 었다. 1945년 9세, 그는 해방을 맞이하였고 2년 후인 11세 때 최인훈과 그의 가족은 북한 체제 하에서 부르주아로 분류되 며 원산으로 정치적 피난을 가게 된다. 원산으로 간 최인훈 은 초등학교 6학년에서 중학교 2학년으로 월반하게 되는데 학교 벽보에 쓴 글이 문제가 되어 선생님들 앞에서 자아비 판을 하기도 하였다. 1950년 14세, 6.25 전쟁이 발발하여 월 남을 하게 된 그는 1년간 부산 피난민 수용소에서 지내다가 목포고등학교에 입학하게 된다. 1952년 16세, 가족은 강원도 영월의 중석 광산에서 제재소 일을 하였고, 최인훈 혼자 피 난 수도인 부산으로 돌아와 서울대 법대에 진학하게 된다. 여기서 그는 자신의 최초의 작품인 '두만강'을 집필하게 된 다. 1956년 20세, 그는 사회적으로 혼란스러운 상황 속에서 학교 수업의 의미를 찾지 못하고 방황하다가 마지막 한 학 기를 남겨두고 중퇴를 하게 된다. 1956년 21세, 최인훈은 통 역 장교로 입대하며 글을 쓰기 시작한다. 1959년 23세, 그의 'GREY 구락부전말기'와 ‘라울전'이 자유문학 10월호에 발표 되며 등단한다. 1960년 24세, 최인훈은 자신의 첫 중장편 소 설인 '광장'을 잡지 '새벽'에 발표하며 유명 소설가의 반열에 오르게 된다. 이후 그는 '구운몽', ‘회색인', '서유기', ‘크리스마 스 캐럴, '가면고', '소설가 구보 씨의 일일', '옹고집뎐', '태풍', ‘총독의 소리’ 등의 소설과 희곡집 '옛날 옛적에 훠어이 훠이', 산문집 '유토피아의 꿈' '길에 관한 명상' 등을 집필한다. 그 는 소설과 희곡을 통해 동인문학상(1966), 한국연극영화예술 상 희곡상(1977), 중앙문화대상 예술 부문 장려상(1978), 이산 문학상(1994), 제1회 박경리문학상(2011) 등을 수상한다. 1973년 37세, 최인훈은 미국 아이오와 대학의 세계작가 초청 으로 4년간 미국에 체류하며 미국으로의 이민을 고민하기도 한다. 1976년 40세, 미국에서 귀국을 한 그는 서울예술대학 문예창작과 교수로 부임하며 소설보다는 희곡 집필에 집중 하게 된다. 1994년 58세, 최인훈은 자전적 성격을 갖는 장편 소설인 '화두'를 집필한다. 2001년 65세, 최인훈은 서울예술 대학 문예창작과 교수를 정년퇴임하고 명예교수로 취임하게 된다. 2018년 82세, 그는 지병으로 인해 사망하게 된다.

‘광장'은 4.19혁명이란 시대적 배경 속에서 탄생하였다. 1960년 4월, 이승만 정권의 장기 집권과 독재에 반하는 4.19 혁명이 일어나게 된다. 이로 인해 이승만 대통령은 하야하 고, 시민들 사이에서는 새로운 사회에 대한 기대와 논의가 활발하게 이루어지게 된다. 더불어 남과 북의 관계와 비판에
자유로워지며 남북한 이데올로기를 비판한 작품을 소설로 발표할 수 있었다.

'광장'은 1960년 11월, 잡지 '새벽'에 첫 발표를 한 이후 2014년에 이르기까지 4개의 출판사에서 발행이 되며 총 7차 례 개정을 거친 만큼 작가에게 큰 애정이 있는 작품임을 알 수 있다. '광장'은 최인훈의 소설 가운데 가장 잘 알려진 소 설로서 남북한 이데올로기를 동시에 비판한 최초의 소설이 자 전후문학을 마감하고 1960년대 문학의 지평을 연 작품으 로 평가되고 있다. '광장' 이후 수많은 분단 소설들이 지어졌 으나 비판적 사실주의적 각도에서 '광장'을 뛰어넘을 작품은 많지 않을 정도로 독보적인 평가를 받고 있다. 본 논문은 2014년 문학과 지성사에서 출판된 판본을 기준으로 작성하 였다(Choi 2014).

\section{‘광장’ 줄거리}

소설은 주인공 명준이 중립국으로 가는 석방 포로를 실은 인도 배 타고르 호에 오르는 장면에서부터 시작된다. 명준은 밤하늘을 날으는 갈매기들을 바라보며 대학에 다니던 자신 의 과거를 회상한다.

명준은 대학을 다니던 어느 가을, 자신이 지은 노래가 대학 신문에 실리자 쑥스럽지만 한편으론 자랑스럽게 대학 신문 을 품에 안고 학교를 걸어간다. 명준은 철학과 3학년 정도 되 면 세상과 삶에 대해 맺음이 있을 것으로 생각하며 아직 아무 런 보람과 결실을 가지지 못한 것에 대해 고민을 하게 된다.

명준은 독립운동을 하던 아버지가 갑자기 월북을 해버리 고, 충격을 받은 어머니가 죽은 후 아버지의 친구인 변선생 의 집에서 기거하고 있다. 명준은 변선생의 자제인 태식과 영미와 친하게 지내나 영화나 댄스파티와 같이 그들이 즐기 는 유흥에는 관심이 없다. 명준은 겉으로는 그들과 어울리는 한편 자신이 아무것도 하지 않고 시간만 보낸다는 생각에 불안해하며 삶을 올바르고 가치 있게 산 사람들이 남겨 놓 은 책을 읽는다. 명준은 책장에 꽂힌 400 권 가량의 책을 훓 어보며 책장을 대할 때마다 흐뭇함과 든든함을 느낀다. 그는 책장에 책이 한 권씩 늘어갈 적마다 몸 속에 깨끗한 세포가 한 방씩 늘어가는 듯한 느낌을 받는다.

어느 날 명준은 영미를 따라 간 댄스파티에서 윤애라는 친구를 소개받고 이성에 대한 호기심을 느끼기 시작한다. 명 준은 여자도 남자와 같이 욕정이 있는지 궁금해하며 윤애에 게 접근한다.

명준은 고고학자이자 여행가인 정선생이 미라를 보여준 다고 하자 수천 년의 역사를 가진 물건을 볼 호기심에 그를 찾아 간다. 명준은 그가 쓴 유명한 두 권의 책이 현재도 인정 받는 것을 보며 그를 존경한다. 명준은 정선생에게 자신이 
어떻게 살면 좋을지 의견을 구한다. 명준은 정선생 앞에서 전체를 위한 광장은 없고 개인의 탐욕만을 채우는 밀실이 가득한 남한의 사회에 대해 비판한다. 자신의 비판에 대해 정선생으로부터 만족스러운 대답을 얻지 못한 명준은 자신 에게 우상이었던 정선생이 친구로 내려오는 것을 느끼며 허 전함을 느낀다.

명준은 월북한 아버지가 평양 대남방송에 나왔다는 이유 로 형사에게 일주일 간격으로 두 번의 심문을 받게 된다. 명 준은 자신이 아버지와 아무런 관련이 없다고 해명하지만 형 사로부터 모진 고문과 모욕을 당한다. 명준은 일방적인 폭행 속에 일본 강점기 일본 경찰들로부터 고문을 당했을 독립투 사 아버지를 떠올리며 어린 시절 집에 들어오지 않아 서운 하게 생각했던 아버지의 상황과 마음을 이해하게 된다.

윤애의 집으로 거처를 옮긴 명준은 자신에게 밥을 차려주 고, 잠잘 곳을 마련해주는 윤애에게 고마움을 느낀다. 바닷 가에서 윤애와 깊은 키스를 나누고 윤애의 몸을 애무하며 흐뭇한 기쁨을 느낀다. 하지만 자신과의 잠자리를 거부하는 윤애의 모습을 보며 명준은 윤애에게 넘을 수 없는 벽이 있 음을 느낀다. 명준은 이름 모를 애인이 자신을 부르는 꿈을 꾼 뒤 새로운 광장으로 가는 것을 상상하며 아버지를 찾아 밀수선을 타고 월북하게 된다.

하지만 명준이 북녘에서 만난 것은 잿빛 공화국이었다. 북 한에 도착한 명준은 오직 당과, 당을 위해 살아가는 사람들 만 존재하며 개인적인 것은 모두 금기시되는 것을 보고 북 한 사회에 크게 실망한다. 명준은 아버지를 만나 북한에서의 삶에 대한 실망감을 토로하나 묵묵히 듣기만 하는 아버지의 모습에서 실망하며 집을 나와 야외 국립극장 짓는 일에 자 원한다.

명준은 공사장에서 발을 헛디뎌 오른쪽 허벅지 빼에 금이 가는 사고로 병원에 입원하게 된다. 명준은 다른 사람의 병 문안을 온 국립극장 발레리나 은혜를 우연히 만나게 되고 윤애를 닮은 그녀의 모습에 반하여 교제를 시작한다. 신문 기자로 일하게 된 명준은 중국 만주에 있는 '조선인 콜호스' 의 생활에 대한 글을 쓰게 된다. 명준은 일제의 군복을 입고 일하는 동무들의 모습을 사실 그대로 신문에 보도하여 당을 모욕했다는 이유로 당으로부터 자아비판을 강요 받는다. 명 준은 갑작스레 은혜가 러시아로 공연을 가게 된다고 하자 은혜가 한 번 떠나면 다시는 볼 수 없을 것 같다는 생각에 은 혜에게 가지 말아 달라고 애원한다.

은혜가 러시아로 떠난 후 한국전쟁이 발발하자 명준은 군 에 자원한다. 낙동강 전쟁터로 오게 된 명준은 간호병으로 참전한 은혜를 다시 만나게 된다. 명준은 다른 사람들은 알 지 못하는 동굴에서 그녀와 몰래 만나며 위안과 행복을 느
낀다. 마지막 총공격이 있기 전 동굴에서 은혜를 만난 명준 은 은혜로부터 딸을 임신했다는 애기를 듣지만, 며칠 뒤 그 녀의 전사 소식을 접하고 만다.

휴전협정이 맺어지고 포로 송환이 시작되면서, 명준은 남 과 북 어디에도 자신의 광장이 없다는 생각에 중립국을 선 택한다. 자신이 지나온 나날을 회상한 후 중립국에서의 새로 운 자신을 상상하던 명준은 새 삶의 길 속에서 희망이 아닌 허전함을 느낀다. 명준은 자신을 따라오는 갈매기들이 자신 을 감시한다고 느끼고 갈매기들의 울음소리가 자신을 비웃 는 듯이 생각되자 참을 수 없는 분노를 느끼며 사냥총을 가 져와 조준한다. 두 갈매기를 자세히 본 명준은 한 갈매기가 다른 갈매기보다 크기가 작다는 사실을 알게 되었고, 자신을 부르는 은혜의 목소리를 듣게 된다. 큰 갈매기와 작은 갈매 기는 은혜와 자신의 딸이었음을 알게 된 명준은, 두 갈매기 가 날고 있는 푸른 바다가 자신의 마지막 광장임을 깨닫는 다. 그날 이후 배에서 명준을 본 사람은 없었으며, 타고르 호 를 따라오던 두 갈매기의 그림자 또한 더는 보이지 않았다.

\section{청소년기 주요 발달과제와 성인기 진입}

소설에는 명준의 나이가 명확히 기술되어 있지 않다. 하지 만 여러 개정판의 내용을 토대로 보면, 1945년 광복 이후 아 버지가 월북한 뒤 어머니가 죽을 때를 19-20세로 추정할 수 있다. 2년 후인 21-22세 때 명준은 대학교 3학년으로 삶과 자신에 대한 고민을 시작하게 된다.

Gilmore와 Meersand (2015)는 청소년기를 초기 청소년기 (13-15세), 중기 청소년기(15-17세), 후기 청소년기(18-23세) 로 구분하였다. 청소년기의 시기와 나이의 경계를 설정함에 있어 분석가마다 차이는 존재하지만, 저자들은 이를 바탕으 로 '광장'에서 명준이 청소년기를 거치며 경험하는 일들과 내면화 변화를 살펴보고자 한다.

명준은 아버지의 월북과 어머니의 죽음 이후 본의 아니게 자립을 하게 된다. 혼자가 된 명준은 철학과 3학년의 대학생 으로, 사회에서 어떤 일을 통해 보람을 느낄 수 있을 지 궁금 해하며 열심히 살아간 이들의 책을 읽지만 뚜렷한 방법을 찾지 못함에 괴로워한다. 한편 명준은 변선생의 아들이자 자 신과 동갑인 태식, 여동생인 영미와 함께 생활한다. 명준은 친구들과 어울리길 좋아하는 영미를 따라 파티장, 피크닉, 영화관 등을 가게 된다. 하지만 명준은 그들과 어울리는 자 신의 모습에서 무엇인가 허전함을 느끼며 친구들 사이에서 겉돈다. 어느 날 파티에 참석한 명준은 흰색 드레스를 입은 영미의 뽀얗고 가느다란 팔에 눈길이 가게 된다. 명준은 파 티에서 영미의 친구 윤애를 만나게 되어 같이 살게 된다. 윤 애와 바닷가를 산책하던 명준은 윤애와 입을 맞추는 등의 
신체적 접촉을 한다. 하지만 명준은 윤애와 끝내 깊은 관계 를 맺지 못하며 윤애의 집을 나오게 된다.

이와 같은 명준의 생활 모습은 청소년기에 부모로부터 신 체적 심리적 독립을 이루고, 자신의 정체성을 찾으며, 사회 적 반경을 넓혀가는 탐색 과정(exploration)을 잘 묘사한 것 이다. 또한 명준은 또래 아이들과 어울려 다니며 세상을 경 험하고, 이성에 대한 열망과 호기심이 발달하는 것을 관찰할 수 있다. 이런 청소년기의 정신발달은 발달과제적 측면에서 나눠서 볼 수 있는데 초기, 중기, 후기로 세분화가 가능하다. 연령대는 문화적 아치, 개인의 발달 차이에 따라 다를 수 있 으나 일반적 제시임을 감안해야 한다.

초기 청소년기는 13 세에서 15 세에 해당되며, 사춘기의 호 르몬 변화를 통해 초경과 몽정을 하며 신체 변화가 시작되 는 시기이다. 이때 청소년은 성적으로 변화하는 자신의 신체 에 적응하며 외모에 대한 관심이 증가한다. 청소년기에는 아 동기에 가졌던 부모와의 친밀감이 줄어들고 자율성을 주장 하며 부모로부터 심리적 거리를 두기 시작한다. 또래 관계에 서 자신이 어떻게 받아들여지는지가 자존감 형성에 매우 큰 영향을 미치게 되며, 또래들과의 우정이 매우 중요해진다 (Gilmore와 Meersand 2015).

중기 청소년기는 15 세에서 17 세로, 부모로부터 심리적으 로 독립하려는 경향이 생기면서 부모와의 갈등이 심해지는 시기이다. 인지적으로는 형식적 조작기(formal operational stage)에 해당되면서 자기 중심적인 사고가 강해지고 일종의 전능 망상(omnipotent fantasy)이 생길 수 있다. 청소년은 부모에 대한 의존을 포기하면서 자신의 한계를 느끼게 되고 자기애적 경향이 강해질 수 있다. 청소년은 정체성에 대한 고민을 시작하며 현실 세계에 뛰어들 준비를 하기 위해 직 업을 탐구한다(Gilmore와 Meersand 2015).

후기 청소년기는 18 세에서 23 세에 해당된다. 하지만 청소 년기가 끝나는 정확한 시기를 특정하기 위해서는 문화, 사 회, 시대적 요소를 고려해야 한다. 후기 청소년기는 청소년 기 발달과제들을 해결하고 통합하는 시기이다. 정체성의 확 립, 부모로부터 분리 개별화, 초자아의 재정립, 친밀한 관계 안에서 애정과 성적 욕구를 통합하여 경험하는 것이 필요하 다(Gilmore와 Meersand 2014). Erikson (1959)은 자아 정체 성(ego identity)을 찾는 것을 청소년기의 가장 중요한 발달 과제로 보았고 자신만의 정체성을 찾지 못할 경우 역할 혼미 (role confusion)를 경험할 수 있다고 보았다. 그는 이 시기에 청소년들이 스스로의 정체성을 찾기 위한 일종의 '타임아웃' 시기인 심리사회적 유예기간(psychosocial moratorium)을 가질 수 있다고 했다.

청소년기 발달 과제를 원만하게 성취하지 못하면 성인기
진입에 어려움을 겪을 수 있다. 이때 청소년기가 길어질 수 있는데 이를 청소년기의 연장(prolonged adolescence)이라 고 불렀다(Bernfeld 1923; Blos 1954). 그리고 세 시기의 발 달 요소들은 순서대로 오는 것은 아니며 개인의 특성과 상 황에 따라 혼재된 순서로 오거나 존재하지 않고 넘어가기도 한다. 일부는 문제가 되지 않기도 하지만 어떤 것은 성인기 에 늦게 표면위로 올라와 갈등의 원인이 되기도 한다.

성인이 된다는 것은 청소년기의 종료와 함께 오지만 이 시기를 분명히 특정하는 것은 불가능하다. 다만, 일반적 성 인의 심리적 성취를 이해하는 것으로 청소년기에서 성인기 로 진입을 평가하는 것은 가능하다. 성인은 부모로부터 경제 적, 감정적 독립을 이루고 자신과 타인의 감정을 구별하고 통합하는 능력을 가져야 한다(Arnett 1994). 또한 감정적, 육 체적 동반자와 깊은 관계 속에서 감정을 공유하고 상대의 취약성을 이해하고 받아들일 수 있어야 한다(Erikson 1963).

언급된 청소년기 구성요소와 성인기로 진입을 위한 발달 과제를 볼 때 명준은 후기 청소년기의 발달 과정에 있으며, 성인기에 필요한 여러 요소들을 획득하려고 노력은 하나 매 번 좌절과 실패를 경험했던 것으로 보인다. 반복된 좌절과 실패는 명준의 충동적 판단과 돌발적 행동에 무의식적 영향 을 준 것으로 보인다. 한편, '광장'의 초반부에서 관찰되는 명 준의 대부분의 선택과 행동은 청소년기의 주요 발달과 밀접 한 연관이 있는데, 명준은 부모가 존재하지 않음에도 불구하 고 이 시기에 필요로 하는 것을 본능적으로 인식하고 개척하 려는 노력을 한 것을 확인할 수 있다. 청소년기는 성인 세계 인 사회로 진출하기 위해 자신의 지평선을 탐구하고 확장하 는 시기이며, 인생의 기초를 구축하고 안정감과 지속성을 갖 는 훈련을 하는 시기이다(Blos 1962; Levinson 1978). 명준의 예에서 볼 수 있듯이 이 중요한 시기에 온전한 양육환경이 부 재한다고 해도 청소년은 발달 과제를 본능적으로 인식하고 자체적으로 그 대체를 할 대상을 찾을 수 있다. 또한, 많은 청 소년들이 자신의 영역을 확장하려는 시도를 통해 청소년기 의 주요한 발달과제를 무사히 완수해낸다는 것에도 주목할 필요가 있다.

\section{청소년기 분리-개별화 과정과 자기애의 특징}

청소년기에는 다양한 정신발달과제가 주어진다. 자기애 의 발달 또한 이 시기에 두드러지는 특징 중 하나이다. 일반 적으로 자기애는 청소년기에 자기 정체성을 형성하는데 긍 정적 영향을 준다. 청소년기 자기애의 건강한 발달은 성인기 사회에서 만나는 많은 갈등과 좌절을 견뎌내는 원천이 될 수 있다. 하지만 자기애의 병적인 측면이 두드러지게 발달하 거나 강화되면 학교나 부모와의 관계에서 심각한 갈등이 발 
생하거나, 충동적 행동의 동기가 될 수 있고, 성인기로 진입 후에도 사회적응이나 대인관계에 여러 문제가 발생할 수 있 다. 그러므로 청소년기 자기애의 특성을 잘 파악하고, 자기애 의 발달이 어떤 방향으로 진행하는지 관찰하는 것은 무척 중 요하다. 그런 점에서 '광장'의 주인공 명준은 청소년기 자기애 적 측면에서 관찰하고 해석할 점이 많은 것을 확인할 수 있다.

소설 초반, 자신의 노래가 대학신문에 실려 기분 좋은 울 렁임을 느낀 명준은 다른 사람들이 자신을 알아볼 것 같다 는 기대에 신문을 책 사이에 끼고 캠퍼스 안을 자랑스럽게 걷는다.

한편, 보람 있는 특별한 삶을 살고자 독서를 즐겨 하는 명준 은 400 권 가량의 책이 있는 자신의 책장을 보며 책장에 책이 늘어날 때마다 몸 속의 깨끗한 세포가 늘어가는 듯한 느낌을 받는다. 명준은 알렉산더, 칭기즈칸, 갈릴레이, 뉴턴과 같은 위 인들을 열거하며 그들과 같이 될 수 있는 방법을 찾는다.

명준은 평소 존경하던 정선생으로부터 실수를 두려워하 지 말고 일단 어떠한 것이라도 시도해보라는 조언을 듣는다. 그러나 명준은 지금껏 실수한 적이 없기에 앞으로도 그럴 일은 없을 것이고 모든 일을 완벽하게 잘 할 생각으로 그의 조언을 무시한다. 명준은 변선생 집에 머무르며 경제적 부족 함 없이 대학교까지 다녔지만 그의 도움을 감사해 하기보다 당연하게 여긴다.

이성에 대한 관심이 높아진 명준은 애인을 만들게 되면 정 신적 교감을 포함하여 여러 가지 신경 쓸 일이 많이 생긴다 는 생각에 이성과 육체적 교감만을 나누고 싶다고 생각한다. 며칠간 윤애와 신체적 접촉을 시도한 명준은 끝내 윤애가 자 신을 거절하자 윤애에게 한마디 말없이 집을 떠나 버린다.

'광장'에서 보이는 명준의 행동들은 모두 전형적인 청소년 기의 자아중심적이고 자기애적인 판단과 행동을 묘사하고 있다. 남들이 모두 자신을 부러워할 것이라 생각하고, 지식 을 쌓는 것을 자아의 팽창으로 과대자기의 일부로 받아들이 며 세계의 위인들과 동일시한다. 어른의 조언을 무시하며 불 멸과 완벽의 환상을 유지하고, 감사의 마음을 갖지 않고 표 현하지 않는다. 이성에 대해서 자기중심적 태도를 가지면서 거절에 대해 자기애적 분노와 냉담을 행동으로 표현한다.

이런 모습들을 전체적으로 보면 건강한 자기애와 병적인 자 기애가 혼재된 양상이다. 이 둘은 구별하기 어려운데 이를 위 해서는 청소년기의 자기애 발달 과정을 파악할 필요가 있다.

청소년기는 자존감(self-esteem), 자기 가치감(self-worth) 에 대한 자각이 시작된다. 동시에 자기애적 취약성과 연관된 당황스러움과 부끄러움, 수치심과 같은 감정도 쉽게 느끼기 시작한다(Bleiberg 1994). Blos (1962)는 청소년의 분리-개 별화 과정에서 아동기 정체성에 대한 애도 과정이 촉진되고
취약해진 자아를 보완해 발달적 성취를 이루는 과정에서 자 기애적인 반응이 발생한다고 보았다. 이러한 자기애적인 반 응은 낮은 자존감을 향상시켜주고 우울하고 공허한 기분에 대처하고 독립적인 개체로 활동할 수 있도록 돕는 한편, 전 능감이 강화된 채 유지되기도 한다.

명준은 청소년기 아버지의 월북과 어머니의 급작스러운 죽음으로 인해 준비되지 않은 분리-개별화 과정을 경험하 였다. 이러한 경험은 명준의 자기애 발달에 부정적 영향을 준 것으로 보인다. 준비되지 않은 분리-개별화는 정체성 혼 란과 함께 자기애적 반응이 강하게 작동하는 계기가 된다. 명준은 수백 권의 책을 읽으며 지식을 쌓고 위인을 동일시 하는 반면 현실 사회에서의 부조리와 모순을 비판하기도 한 다. 이러한 명준의 행동은 과대 자기를 유지해 부모의 갑작 스러운 부재를 극복하고 자존감을 향상시키려는 자기애적 방어로 볼 수 있다. 이러한 명준의 노력은 일부 성공하였으 나 또한 쉽게 무너져 실패하기 쉬운 상태로 보인다.

대학신문에 자신의 노래가 실린 것을 다른 사람들이 알아 보지 않을까 생각하며 자랑스럽게 캠퍼스를 걸어 다니는 명 준의 모습에서 타인 또한 자신과 같은 관심사를 가질 거라 믿는 청소년기 자아 중심적 모습이 관찰된다. 보람 있는 일 을 하며 자신의 가치를 증명하고 싶어하는 명준은 책 속의 위인들 과의 동일시를 통해 여러 위인들과 같은 큰 일을 하 고 싶어한다. 이러한 명준의 모습에서 독특함과 전능감의 특 성을 갖는 자아 중심적인 자기애 특성이 두드러지는 것을 확인할 수 있다.

이렇게 자신에게 몰두하는 현상은 청소년기에 특수하게 관찰되며, 자신과 타인의 관심사를 적절하게 구분하지 못하 는 인지적 경향성이다. Elkind (1967)는 청소년기 자아 중심 성은 타인의 입장에서 스스로를 바라볼 수 있게 되면서 해 소되는데, 이를 위해 인지적 발달뿐 아니라 가까운 또래와의 우정을 경험하는 것이 필요하다고 주장했다. 이는 타인과 가 까운 정서적 상호작용을 경험하게 하며 상호간의 중요성과 의지함을 인정하게 한다. 이 과정을 통해서 자연스럽게 자기 애적으로 경직된 자아중심성은 서서히 줄어든다.

이러한 청소년기 자아 중심적 경향은 청소년기에 증가하 는 모호성을 극복하려는 시도, 어린아이도 성인도 아닌 상태 에서 자신만의 사회 문화적 위치를 찾으려고 하는 노력으로 해석하기도 한다(Martin과 Sokol 2011). 즉, 청소년기 자아 중심성은 청소년이 부모와의 갈등과 독립 속에서 자신만의 자아 정체성(ego identity)을 형성하려는 노력의 일환으로 볼 수 있다.

이런 점들을 고려할 때 명준의 행동들은 청소년기의 자기 애적 특징들이 두드러지게 나타났고, 이는 아버지의 월북, 
어머니의 사망과 같은 큰 사건들이 10 대에 일어난 것이 영 향을 준 것으로 추정하게 된다. 이와 같이 심리발달의 궤적 에서 청소년기에 2 차 분리-개별화를 진행하는 시기에 경험 하는 부모와 관계의 예상하지 못한 단절은 강한 자기애적 방어를 불러일으키고, 이는 건강한 자기애의 발달에 부정적 영향을 미칠 수 있다.

\section{청소년기 오이디푸스 재활성화를 통한 자기애의 수정}

청소년기는 오이디푸스 콤플렉스가 재활성화 되는 시기이 다. 자신만의 정체성을 형성해가는 청소년에게 오이디푸스 콤플렉스는 이상적인 부모상과 과대 자기에 대한 수정을 거 치며 자기애의 성숙을 이룰 기회로 작용한다. '광장'에서 관 찰되는 명준의 청소년기 오이디푸스 콤플렉스의 재활성화 과정을 살펴보고 오이디푸스 콤플렉스와 자기애의 관계, 그 리고 청소년기 부모의 역할에 대해 분석해보려고 한다.

초자아의 발달은 오이디푸스 콤플렉스의 해소와 함께 시 작된다. 이때 소년에게 아버지의 실제 존재는 오이디푸스 콤 플렉스를 경험하고 해소하는데 영향을 준다.

'광장'에서 명준은 독립운동을 했던 아버지를 따라 신경, 하얼빈, 연길 등의 중국 도시를 옮겨 다니며 자랐지만 수 개 월에 한 번 아버지의 얼굴을 볼 수 있을 정도로 만남의 절대 시간은 적었다. 아버지와 충분한 시간을 보내지 못했던 명준 은 긍정적이건 부정적이건 오이디푸스 콤플렉스를 직면할 기회가 적었고, 이는 오이디푸스적 경쟁과 동일시 대상의 상 실을 의미한다. 명준은 이를 책 속의 위인들과 여러 명의 멘 토들로 대체하려 한 것으로 보인다.

위인들과의 동일시는 명준에게 높은 기준의 자아 이상과, 엄격한 초자아를 형성하는 데 기여한 것으로 보인다. 이는 명준이 위인들 같이 이른 나이에 무언가를 성취해야 한다는 압박과 불안을 느끼게 한 것으로 보인다. 명준은 수백 권의 책을 읽는 강박적인 행동을 보이며 자신을 발전시키는데 몰 두한다. 이는 결국 명준이 외부 대상들과 유연한 관계를 맺 는 데 방해를 주어 현실 적응에는 큰 도움이 되지 않았고, 유 연한 초자아의 발달이 이루어지지 않은 것으로 보인다. 이런 점은 '광장'에서 명준의 일부 행동으로 나타난다.

북한에 간 명준은 기자가 되어 만주의 조선인 콜호스를 취재한다. 명준은 당의 선전과는 정반대로 조선인 콜호스에 지내는 사람들이 일본군이 버리고 간 의복을 주워 입을 정 도로 가난한 모습을 보게 된다. 명준은 당의 거짓된 선전을 바로잡아야 한다며 취재한 내용을 여과 없이 신문에 내보내 버리고, 당으로부터 자아 비판을 강요당한다.

후반부 명준은 중립국으로 가는 타고르 호에서 통역을 담 당하게 된다. 장시간의 항해에 지친 동료들은 명준에게 홍콩
에 들러 쉴 수 있도록 선장에게 요청해 달라고 부탁한다. 그 러나 명준은 선장에게 말을 전하지 않고 하선은 없다는 선 장의 원칙을 고수하였고, 이에 화가 난 동료들 사이에서 이 내 외톨이가 된다.

이와 같은 명준의 완고함은 초자아가 유연하게 작동하지 못함을 의미하며, 이는 명준의 오이디푸스 콤플렉스의 해소 에 어려움이 있었음을 추정할 수 있다.

비록 소년기에 오이디푸스 콤플렉스의 해소에 어려움이 있다 해도 청소년기에 다시금 재활성화 되기 때문에, 소년기 에 이루지 못한 오이디푸스 콤플렉스의 해소를 잘 해결할 수 있는 기회가 온다. 만일 아버지의 부재로 소년기에 오이 디푸스 콤플렉스를 경험할 기회를 제대로 갖지 못했다면 청 소년기에 오이디푸스 콤플렉스의 재활성화가 일어나면서 이를 정면으로 다루려는 욕구가 발생한다. 명준에게도 그런 기회가 자연스럽게 찾아온다. 명준은 사회에서 무엇을 해야 할지에 대한 해답을 찾고 이성에 대한 호기심을 해결하고자 평소 존경하던 정선생을 찾아가 조언을 구하며 자신의 성장 을 도와줄 새로운 대상을 찾는다. Blos (1962)는 청소년기를 부모로부터 독립하면서 자신만의 정체성을 형성하는 시기 로, 새로운 가치의 기준을 보여줄 새로운 대상을 열망하는 시기로 보았다. 정선생은 평소 명준이 존경하는 고고학자이 자 여행가로 그가 출간한 책 두 권은 현재까지 꾸준히 팔릴 정도로 인정을 받는 사람이다. 명준은 마흔 살이 넘도록 결 혼을 하지 않은 정선생에게 결혼을 하지 않은 이유에 대해 물어보는 등 평소 궁금하던 많은 것들을 물어보고 정선생은 성의껏 대답을 해준다. 하지만 명준은 정선생도 자신과 같이 남한사회에서 적응하고 성공할 뚜렷한 방법을 모른다는 사 실을 깨닫고 이해하기 어려운 이성관을 가진 정선생의 모습 에 실망한다. 결국 명준은 정선생을 우상이 아닌 친구로 여기 며 정선생을 평가절하하며 거리를 두기 시작한다. 이후 명준 은 자신의 정체성, 자아 이상의 형성을 도와줄 새로운 대상을 찾고자 노력한다. 형사로부터 모진 고문을 받게 된 명준은 독 립투사로 활약한 아버지도 이전에 숱한 고문과 억압 속에 어 려움을 겪었을 것으로 생각한다. 아버지의 과거 상황을 이해 하게 된 명준은 보이지 않는 아버지와 동일시를 하며 아버지 의 실체를 보고 싶다는 현실적 욕구를 느끼게 된다. 이런 욕 구로 인해 명준은 밀수선을 타고 북한으로 가게 된다. 명준은 과거 독립투사로 활약한 아버지와 유사한 경험을 한 이후에 정선생이 아닌 북한에 있는 아버지를 직접 만나 관계를 갖고 싶어한다. 이러한 생각의 변화는 명준의 청소년기 오이디푸 스 콤플렉스가 재활성화 되는 근거로 볼 수 있다.

하지만 북한에 간 명준은 대궐과 같은 집에서 살면서 사 치와 부귀를 누리며 자기 나이 또래의 새로운 부인을 맞이 
한 아버지를 발견하고 큰 실망을 한다. 명준은 위험을 무릅 쓰고 월북을 했지만 얻은 것은 없이 실망하며 아버지의 집 을 나오게 된다. 청소년기의 자기애적 불멸의 환상은 명준으 로 하여금 죽음의 위기를 감내하고 북한으로 가도록 이끌었 다. 명준은 아버지를 만나 다시 안전하고 완벽한 동일시와 이상화를 완성하고 안정적인 오이디푸스 콤플렉스의 완성 을 기대했던 것이다. 그렇지만 명준의 강한 초자아는 기대와 다른 아버지의 삶에 강한 비판을 하도록 하였고, 그의 동일 시의 대상으로 받아들일 조건을 만족하지 못한다고 여기게 하였다. 결국 명준은 그토록 바라던 아버지의 집을 나오게 된다. 명준의 행동은 권위적 대상에 대한 복종이나 순응을 거부하는 청소년기의 특징이기도 하다. 반면, 이 시기의 혼 란에 대해 다소 자기중심적 자기애를 유지하려는 방어적 태 도로도 볼 수 있다.

명준의 이러한 행동은 아버지 삶의 불완전함을 받아들일 수 없었기에 발생한 것으로 보인다. 청소년기에는 아동기와 달리 자신과 부모의 모습에서 불완전함을 발견하고 받아들 이게 된다. 청소년은 부모가 자신의 유아기적 기대에 미치지 못하는 것을 이해하게 되며 보다 현실적인 부모의 측면에 대한 선택적 함입과 동일시를 경험한다. 이를 통해 청소년은 자신의 이상적인 모습에 대한 기준을 수정하고 발전해 나간 다. 그 결과 아이는 부모 외의 다른 새로운 대상을 동일시할 수 있는 가능성을 열어 두게 되며 이를 통해 좀 더 현실적인 재능과 기회를 얻을 수 있게 된다(Tyson과 Tyson 1984). 따 라서 오이디푸스 갈등의 재경험을 통해 이상적인 부모상과 과대 자기에 대한 수정을 거친 청소년은 보다 성숙한 자기 애를 형성하게 된다. 성숙한 자기애의 형성은 안정적인 자존 감 유지에 도움을 주며 사회에서의 성취 및 대인관계를 통 한 사랑과 만족을 느끼는 데 기여하게 된다.

그러나 '광장'에서 명준은 아버지의 모습을 인정하고 받아 들이며, 현실적 동일시의 대상으로 인정하지 못했다. 청소년 기 동일시를 통한 자아이상의 수정과 발달이 이루어지지 않 게 되면 낮은 자존감이 지속되거나, 불가능한 목표를 향한 지속적인 투쟁, 자신의 이상적 기준에 맞지 않는 유아기적 대상에 대한 평가절하와 같은 자기애의 문제가 발생할 수 있다(Tyson과 Tyson 1984). 특히 청소년들은 실패로부터 자 신을 보호하기 위해 사회적 현실 측면에서 철수하거나 그것 을 평가절하 하기도 한다(Kernberg 1975). 아버지를 만난 이 후 명준은 자신의 정체성을 찾지 못한 남한과 북한의 사회 에서 철수하며 자신을 발전시켜줄 새로운 대상을 찾아 중립 국으로 가게 된다. 이러한 명준의 행동에서 불가능한 목표를 향한 지속적인 투쟁, 사회적 현실 측면에서의 철수, 정체성 형성과 같은 발달의 어려움을 겪는 것을 확인할 수 있다.
명준은 완벽한 아버지를 만나기를 고대했으나 아버지는 명준의 환상을 충족시켜 주지 못하며 명준이 오이디푸스 콤 플렉스를 마주하는 데 어려움을 주게 된다. 청소년기의 중요 한 과제는 부모가 이상적인 대상이 아니라는 것을 인정하고 받아들이는 것이다. 청소년기 이상화 된 부모상의 유지와 과 대 자기의 지속은 청소년기 건강한 자기애의 형성에 방해가 될 수 있다.

독립 투사로 명예롭고 완벽해 보이는 아버지의 존재는 아 동기와 청소년기 명준이 이상화 된 아버지상을 형성하도록 만든 것으로 보인다. 한편, 소년기 아버지와의 불안정한 만 남 속에서 명준은 아버지로부터 버림을 받을 수 있다는 유 기 불안을 느꼈을 가능성이 높다. 따라서 명준은 아버지로부 터의 사랑과 인정을 받기 위해 자신에게 엄격하고 높은 기 준을 갖게 되었을 것이라 짐작할 수 있다. 더 나아가 그가 읽 은 책의 훌륭한 위인들 과의 동일시는 명준의 높은 기준을 강화했다. 오이디푸스기를 거치며 초자아가 형성되고 수정 되는 과정에서 아이가 생각하는 부모의 이상화 된 이미지가 지나치게 오래 지속될 경우 비현실적인 만족에 대한 기대가 지속될 수 있다. 부모의 이상화에 대한 병적인 고집은 자기 만족을 유지하려는 환상이며 아이가 현실 속 대상과 관계를 맺는 데 방해물이 된다(Tyson과 Tyson 1984). 따라서 자기 와 타인을 통합하고 사랑하는 능력에 어려움을 겪으며 자기 자신과 세상에 대한 완벽함을 유지하려는 병리적인 자아 이 상을 형성할 수 있다(Blos 1972).

명준은 소년기에 아버지와 지속적으로 만나지 못함으로 써 아버지에 대한 이상화 된 이미지를 수정할 기회를 갖지 못했다. 명준은 아버지와의 관계에서 비현실적인 만족을 기 대한 것으로 보인다. 현실에서 만난 아버지는 그가 그린 존 재가 아니었고, 현실적 관계를 다시 맺어가는데 실패한다. 결국 명준은 청소년기 오이디푸스 갈등해소의 재경험을 통 한 과도한 자기애의 수정과 유연한 초자아의 안정적 발달을 획득하지 못한 것으로 보인다.

'광장'에서 드러난 명준의 행동을 통해 현실에서 청소년기 에 부모의 역할에 대해서 숙고해볼 부분을 발견할 수 있었 다. 청소년기에도 여전히 부모는 내면적으로 완벽한 대상을 투사하는 존재다. 그렇지만 건강한 발달을 위해서는 빈틈을 가진, 완벽하지 않은 대상인 것이 필요하다. 아버지의 불완 전함은 아이가 자신의 불완전함을 받아들이고 성숙한 자기 애를 형성할 중요한 열쇠가 된다.

\section{청소년기의 사랑을 통한 친밀감 형성}

청소년기 자기애적 몰두는 외부의 새로운 대상을 추구하 면서 줄어든다. 이 시기에 대표적인 두 가지가 우정과 사랑 
이다. 친구를 사귀는 것과 이성이건 동성이건 매우 친밀한 가족이 아닌 다른 이를 사랑이란 개념으로 매우 가깝게 사 귀어 보는 것, 그리고 육체적 정서적 교감을 하는 것은 건강 한 자기애 발달, 정체성 형성, 재활성화된 오이디푸스적 욕 동의 재처리 과정에 있어 중요하다(Gilmmore와 Meersand 2015).

'광장'에는 이와 연관해서 명준이 여성에게 호감을 갖고 친밀한 관계를 맺고, 좌절하는 과정이 여러 번 등장한다.

국립극장 공사 중 떨어지며 허벅지를 다친 명준은 위문 차 방문한 국립 발레단원인 은혜를 만난다. 은혜와 매우 가 까운 관계가 된 명준은 이전과 달리 나라의 일은 당 지도부 나 관리들이 잘 이끌어 나갈 것이라고 생각하며 맑은 겨울 의 평화를 느낀다.

당으로부터 자아비판을 강요 받아 상처를 받은 명준은 은 혜에게 자신은 은혜를 믿는다고 말하며 은혜도 자신을 믿는 지 반복적으로 물어본다. 은혜가 모스크바로 3 4달가량 공연 을 다녀올 수 있다고 말하자, 명준은 은혜를 두 번 다시 못 볼 것 같다는 생각에 떠나지 말아 달라고 애원한다. 하지만 은혜 가 말없이 떠나자 명준은 충동적으로 군에 자원입대를 한다.

명준은 전쟁 중 간호병으로 입대한 은혜를 다시 만나게 된다. 명준은 잘못했다며 울며 용서를 바라는 은혜를 받아주 고 전쟁 중 둘만의 동굴에서 은밀한 만남을 갖는다. 은혜의 임신 소식을 듣고 자주 만날 것을 기약하지만 치열했던 마 지막 총 공격에서 은혜는 사망하고 만다.

명준에게 은혜는 매우 중요한 인물이다. 이성과 깊은 관계 를 가질 수 있게 되면서 이전까지 집중하던 자기애적 추구 에 더 이상 비중을 두지 않고, 둘의 관계 안에서 만족과 행복 을 느낀다. 명준은 정치나 국가의 안정과 같은 큰 일은 자신 과 관계에서 멀어지고, 둘의 관계를 잘 이루어 가는 것으로 충분하다고 여겼다. 이는 과대자기를 추구하는 청소년기의 자기애적 측면이 이성과 관계를 경험하면서 서서히 그 비중 이 줄어드는 것을 반영한다. 그리고 은혜의 임신을 받아들이 면서 성인으로서 가족을 이루는 것에 대한 준비를 한다.

이와 같은 다른 중요한 인물과 깊은 친밀한 관계를 경험하 는 것은 청소년기 자기애에서 벗어나는 것뿐 아니라 오이디 푸스 욕동의 재활성화를 승화하고 건강하게 처리하는 데에 중요한 역할을 한다. 청소년은 사랑과 우정이라는 친밀한 경 험을 반복하며 성인기로 진입한다. 이후 타인과 친밀함을 형 성했던 경험은 초기 성인기 가장 기본적인 발달과제인 친밀 (intimacy)을 형성하는 발판이 된다. 반면 타인과 진정한 상 호관계를 갖지 못할 경우 고립(isolation)을 경험하게 된다.

발달의 측면에서 보면 2차 성징이 발현되면서 잠복기 동 안 억제되었던 이성 부모를 향한 오이디푸스 욕동은 재활성
화가 되며 새로운 위협이 된다. 신체적 성장을 이룬 청소년 은 실제 근친이 가능할 수도 있다는 생각에 자신의 오이디 푸스적 공상과 소망을 재처리할 필요성이 의식표면으로 다 양한 방식으로 올라온다. 이때 이성과 교제는 오이디푸스기 의 성적 대상들 과의 정신 내적 연결을 느슨하게 하여 오이 디푸스 콤플렉스의 재활성화가 가져온 내적 긴장을 줄일 수 있다(Colarusso 1992).

그러기 위해서는 오이디푸스 콤플렉스와 연관된 무의식 적 인식이 다른 이성과의 만남에서 경험하는 과정이 과도기 적으로 필요할 것이다. '광장'에서도 이와 연관한 묘사가 등 장한다.

은혜는 윤애가 보여주던 순결 콤플렉스는 없었다. 순순히 저를 비우고 명준을 끌어들여 고스란히 탈 줄 알았다. 그런 시간이 끝 나면 그녀는 명준의 머리카락을 애무했다. 가슴과 머리카락을 더 듬어오는 손길에서 그는 어머니를 보았다. 어머니와 아들, 아득한 옛적부터의 사람끼리의 몸짓(p145).

이와 같이 은혜는 명준이 어머니와 관계에서 보살핌을 받 던 관계에서 시작하여 오이디푸스적 소망이 실현되는 관계 로 복합적으로 이어지는 성인기의 애정의 대상이 되는 것을 확인할 수 있다.

은혜에게 자신을 믿는지 반복적으로 물어보는 명준의 행 동에서 은혜와 신뢰적 관계를 형성하려는 노력을 볼 수 있 다. 또한 자아비판회로 인해 자존감의 상처를 입었을 때 물 어보았던 것을 볼 때 명준은 은혜를 통해 낮아진 자존감을 채우려 했던 것이다. 타인과 신뢰를 형성하는 일은 자존감의 형성과 유지에 중요하다. 안정된 자존감의 형성은 안정적인 대인관계를 지속할 원동력이 된다. 청소년은 이성과의 관계 에서 때론 거절에 대한 엄청난 공포와 피할 수 없는 자기애 적 손상을 경험한다. 하지만 다시금 사랑에 빠져드는 능력은 강함과 회복력의 지표이다(Colarusso 1992).

은혜가 한 마디 말없이 모스크바로 떠나자 명준은 은혜로 부터 버림을 받았다는 생각에 좌절과 실망을 느끼며 군에 입대하게 된다. 하지만 명준은 자신을 찾으러 전쟁터까지 온 은혜를 용서하고 받아들인다. 은혜의 부족한 모습을 받아들 인 명준은 자신도 은혜에게 의지할 수 있는 존재임을 받아 들이는 것으로 볼 수 있다.

한편 자신에게 용서를 바라는 은혜를 받아주는 명준의 행 동은 자기애적 좌절과 분노로 인한 충동적 행동으로 해석할 수 있다. 돌아온 은혜를 '용서'한다는 판단은 성인기의 성숙 한 관계에서 볼 수 있는 감정반응이 아니라 미숙한 자기애 적 관점에서 작동하는 자기중심적 판단이었다. 이와 같이 명 
준은 비록 은혜와 사랑을 하고, 은혜가 자기 삶을 위해 떠나 면서 좌절과 자기애적 상처를 받는다. 그 상처를 깊이 간직 한 명준은 은혜와 재회했을 때 온전한 기쁨과 안심이 아닌 자기 피해에 대한 용서라는 방식으로 인식한다. 여전히 청소 년기의 자기애가 중심인 발달단계에 머물러 있는 자아의 기 능이라는 것을 확실히 보여주는 장면이다.

일반적으로 사랑스럽고 성적으로 친밀한 이성과의 관계 는 청소년에게 깊은 만족감과 행복감의 원천이 된다. 나아가 열정적인 누군가를 사랑한 경험은 자신의 정체성 성립을 돕 고 자기애의 균형적 발달을 돕는다. 또한 동반자에게 의존을 하는 능력을 갖는 동시에 자신의 자존감을 향상시킬 수 있 다. 상대방을 향한 헌신적인 사랑의 경험은 애정, 충실, 이상 화, 욕망, 신뢰와 같은 중요한 감정의 발달을 돕는다(Gilmmore와 Meersand 2015). 이성과의 상호작용에서 청소년들 은 진정한 감정, 서로를 보는 관점, 자신의 미래계획, 희망, 그리고 기대에 관해 끓임없이 이야기함으로써 자신이 누구 인지를 되찾으려 한다(Erikson 1959).

이런 발달과정의 욕구는 명준이 돌아온 은혜와 동굴에서 꾸준히 은밀하게 만나면서 은혜의 임신까지 이어지게 하였 다. 명준과 은혜는 자신들만의 신뢰와 친밀감의 공간인 동굴 속에서 만남을 이어가게 된다. 명준은 은혜와의 만남을 통해 전쟁의 고통을 잊는다. 또한 명준은 은혜와 전쟁이 끝난 후 의 삶을 이야기 하며 삶의 만족과 행복함을 느끼게 된다.

성인은 깊은 감정적 유대감을 경험한 동반자와 함께 새로 운 가정을 꾸리게 된다. 부모의 품을 떠나 동반자와 함께 가 정을 꾸리고 아이를 낳은 것은 부모와의 오이디푸스 갈등의 해소를 의미하며 성인기의 주요한 발달과제이기도 하다.

은혜의 임신은 명준에게 있어 은혜와의 깊은 친밀감의 징 표로서 새로운 가정을 꾸릴 수 있는 오이디푸스 갈등의 해 소를 의미하며 성인이 될 수 있는 기회로 작용한다. 하지만 은혜의 죽음은 명준의 발달적 성취를 방해하며 명준의 방황 을 다시금 불러일으키게 된다.

\section{광장의 의미}

소설에서 광장은 다양한 의미와 상징으로 사용된다. 이중 명준의 내면에서 광장의 의미가 무엇인지 살펴보려고 한다.

먼저 광장은 남한과 북한, 다른 이데올로기를 가진 체제를 비교하는 것이다. 광장은 집단의 공간을 의미하고 밀실은 개 인의 공간이다. 두 가지 대립적인 표현을 통해 남북한의 이 념 차이를 나타낸다.

광장이 이렇게 명준에게 놓은 사회적 환경을 상징한다면, 그의 내면에서 광장은 다른 방식으로 변화한다. 그에게 광장 은 그의 정신세계를 펼친 너른 공간이다. 명준은 아버지의
광장이 있는 북한으로 가지만 변해버린 아버지의 모습에 대 해 실망하며 아버지의 광장을 나온다. 후기 청소년기로 자신 의 자아 이상과 정체성에 대해 고민을 하는 명준은 아버지의 광장을 찾아가 동일시하고 그곳에서 발전을 원하지만 실패한 다. 그는 그에게 맞는 광장을 찾아 떠돌고 있는 것이다.

한편 명준은 윤애, 은혜와 교제를 할 때 함께 광장에 같이 서 있는다는 표현을 사용한다. 이때 광장은 이성과의 신체 적, 정서적 친밀감을 형성할 수 있는 공간을 의미한다. 특히 명준은 은혜와 신뢰를 쌓고 친밀감을 형성하는 동굴을 자신 의 마지막 광장으로 생각한다. 여기에서의 광장은 은혜, 윤 애와 같은 이성과 하나가 되어 대양감(oceanic feeling)을 경 험하는 심리적 공간이다. 항상 외롭고, 고립되어 있다고 여 기던 명준에게 동반자의 존재는 충분히 광장에 함께 하고 있다는 커다란 충족감을 줄 수 있었을 것이다.

따라서 명준에게 광장은 청소년기 오이디푸스 콤플렉스 의 해소와 자기애의 발달에 있어 명준의 전능적 환상 $\left(\mathrm{om}^{-}\right.$ nipotent fantasy)이 충족되는 공간임을 알 수 있다. 청소년 기에 환상은 억압된 소망의 정신적 표현으로 환상이 실제의 현실이 아니라는 것을 깨달으며 차츰 현실 감각을 갖기 시 작한다(Freud 1911). 전쟁이 끝난 후 명준은 남한과 북한이 아닌 중립국 행을 선택하게 된다. 이러한 명준의 선택은 자 신의 전능적 환상을 충족시켜줄 새로운 광장을 찾고자 하는 환상이 지속되며 포기하지 못하는 내면을 상징한다. 한편 명 준이 남한과 북한의 체제에 불만을 느끼며 각 사회를 밀실 과 광장으로 분리(splitting)하는 의미를 더 살펴볼 필요가 있 다. 이는 전능적 환상이 지속된 명준이 현실의 좋은 측면과 나쁜 측면을 통합시키지 못하기 때문으로 볼 수 있다. 명준에 게 있어 유아적 전능감이 충족되지 않는 남한과 북한은 자신 을 억압하는 한 극단만이 존재하는 사회로 경험한 것이다. 전 쟁으로 남과 북의 분단이 영구화 되어버린 현실에서 명준은 둘의 통합을 이룰 수 없음을 인식한다. 이런 현실적 결함을 인정하기 어려워 명준은 제 3국을 선택한다. 그는 그에게 대 양감의 만족을 주고, 무의식적 환상을 충족시켜줄 광장이 존 재할 것이라 믿는다. 자신의 무의식적 환상이 깨질 수 있음을 직감한 명준이 배에서 바다로 뛰어들어 자살을 하는 것은 이 환상을 현실화하기 위한 자기파괴적 행동으로 이해할 수 있 다. 실제 '대양'과 자신을 하나로 만들어 '광장'에 함입을 한 것이다. 전능적 환상의 공간이 현실에서 존재하지 않는다는 것을 받아들이는 것이 성인기 자아의 주요한 발달 요소이다. 명준은 이러한 발달적 성취를 이루지 못한 것으로 보인다.

\section{정신치료에서의 적용}

'광장'의 명준을 통해 청소년기 자기애의 특성, 성인기에 
자기애의 변형과 성숙이 필요한 이유, 오이디푸스 콤플렉스 의 재활성화가 청소년기나 초기 성인기에 미치는 영향 등에 대해 알아보았다. 이를 기반으로 정신분석적 정신치료를 할 때 고려할 사항을 알아보고자 한다.

\section{안전한 공간에서 신뢰와 친밀감 형성}

과도한 자기애가 유지되며 대인관계에 반복적인 실패를 경험한 청소년은 타인에 대한 신뢰와 친밀감 형성에 어려움 을 겪는 경우가 많다. 이때 환자의 약해진 자아 기능을 고려 하여 자아를 강화하거나 지지하는 입장에서 치료동맹을 형 성하는 것이 중요하다. 특히 청소년은 치료에 대한 동기가 부족한 경우가 많아 치료 동기 형성이 중요한데 이 과정에 서 신뢰와 친밀감 획득이 중요한 역할을 한다.

명준이 신뢰와 친밀감의 대상인 은혜에게 의존하고 위로 를 받는 것에서 볼 수 있듯이 치료자는 환자에게 신뢰와 친 밀감을 전달하는 것이 중요하다. 다른 사람이 접근하지 않는 동굴 속에서 은혜와 친밀감과 신뢰를 형성해 안정감을 느낀 명준은 전쟁의 고통을 극복하며 삶 속에서 안정감을 되찾는 다. 따라서 청소년 정신치료를 함에 있어 환자에게 진료실이 외부 세계로부터 지켜지는 안전한 공간으로 느껴지도록 만 드는 것이 중요하다. 안정감을 느낄 수 있는 치료실에서 신뢰 와 친밀감을 형성하며 청소년 환자가 동기를 가지고 치료에 집중할 수 있도록 돕는 것이 필요하다.

\section{이상화와 평가절하로 인한 역전이를 견디어 주기}

청소년기 자기애가 심한 환자는 치료자를 이상적인 대상 으로 여기는 이상화 전이(idealizing transference)가 나타날 수 있다. 많은 청소년 환자들은 치료자를 이상화하고 치료자 가 자신에게 동일한 이상화를 돌려줄 거울이 되어 줄 것을 기 대한다. 하지만 치료자에 대한 이상화는 곧 급작스러운 평가 절하로 변할 수 있다. Kernberg (1970)는 치료자가 환자의 이 상화와 신뢰를 분노와 경멸에 통합시키면서, 즉 경험의 선한 측면을 악한 측면과 통합시키면서 동시에 죄책감과 타인에 대한 걱정을 불러 일으키는 것으로 치료해야 한다고 보았다.

아버지와 갈등을 경험하는 명준의 행동에서 아버지를 향 한 이상화와 평가절하가 관찰된다. 자기애적 병리를 가지고 있는 환자는 자신의 낮은 자존감을 외부로부터의 인정과 동 일시를 통해 높이려는 시도를 한다. 하지만 상대방의 행동에 서 자신이 받아들일 수 없는 요소들이 발견되면 상대방을 향한 공격성을 띄며 평가절하하게 된다. 이때 치료자는 환자 에 대한 부정적 역전이를 경험하며 정신치료를 중단할 위험 이 발생하기 때문에 이에 대한 대비를 해야 한다. 치료자는 치료자를 향한 환자의 경쟁과 공격성에 대해 지지적인 한편
공감적으로 대하여 환자가 스스로의 공격성에 놀라 치료를 그만두지 않도록 해야 한다. 이러한 시기가 지난 후 환자의 행동을 해석해주면 환자는 자신의 공격성에 대한 죄책감을 갖게 되며 자신과 치료자를 향한 상반된 감정을 통합시켜 안정적인 치료를 유지할 수 있을 것이다.

\section{결 론}

청소년기는 신체적, 심리적 변화 속에서 부모와의 분리개별화를 통해 자신의 위치를 찾고 정체성 성립과 직업 탐 색, 또래 관계의 우정을 경험하고 사랑하는 연인과의 깊은 친밀감을 경험하는 시기이다. 이 때 부모와의 분리-개별화 과정을 겪으며 낮아진 자신의 자존감을 유지하고 발전시키 기 위한 자기애적 반응이 올 수 있다. 청소년기에는 전능감, 자신만의 독특한 존재감, 절대 파괴되거나 다치지 않을 것이 라는 믿음을 갖는 자아 중심적 경향이 두드러질 수 있다.

청소년기에 오이디푸스 콤플렉스의 재활성화는 소아기에 이루지 못한 것을 비로소 해결하고 성인기로 나아갈 수 있는 좋은 기회이다. 청소년은 부모와의 오이디푸스 갈등을 경험 하며 이상적인 부모상과 과대 자기에 대한 수정을 거친 후 보 다 성숙한 자기애를 형성하게 된다. 또한 사랑하는 연인과의 친밀감 형성은 부모를 향한 오이디푸스적 욕동의 재처리와 발달상의 고착과 퇴행을 극복하는데 도움이 된다. 성숙한 자 기애의 형성은 안정적인 자존감 유지에 필요하며 개인의 성 취감 및 대인관계를 통한 사랑과 만족을 느끼는 데 기여한다.

반면 청소년기 오이디푸스 콤플렉스의 해소와 재처리를 통해 소아기와 청소년기 발달과제가 제대로 성취되지 않는 경우 더 큰 혼란과 심적 어려움을 경험할 수 있다. 자기애의 지속을 보인 명준은 현실에 대한 이상적인 기대를 통한 실망 을 반복하며 현실 적응과 대인관계 유지, 정체성 형성에 어려 움을 겪는다. 결국 명준은 자신의 전능적 환상을 충족시켜 줄 광장을 찾는 집착과 방황을 하게 된다. 또한 전능적 환상이 충족되는 공간이 현실에 존재하지 않음을 받아들이지 못할 경우 자기애적 만족에의 퇴행과 자살과 같은 자기애적 파괴 행동을 보일 수 있음을 저자들은 '광장'을 통해 살펴보았다.

그러므로 청소년기의 오이디푸스 콤플렉스의 재활성화와 이와 연관된 자기애적 측면, 자기중심적 심리와 행동은 그런 관점에서 심도있게 바라보고 정신치료를 할 때 중요한 맥락 으로 이해하고 파악하며 다룰 필요가 있다. 치료자는 친밀감 과 신뢰를 통해 자기애가 두드러진 청소년의 정신치료를 실 시해야 한다. 또한, 치료자를 향한 이상화와 평가절하의 공 격성을 견디고 지지해 주어 자신의 감정을 바라보고 통합할 수 있도록 도울 수 있어야 한다. 


\section{Acknowledgments}

None

\section{Conflicts of Interest}

The author has no potential conflicts of interest to disclose.

\section{Author Contributions}

Conceptualization: Jee Hyun Ha, Jae Yong Jang. Data curation: Jae Yong Jang. Formal analysis: Jee Hyun Ha. Investigation: Jee Hyun Ha, Jae Yong Jang. Methodology: Jee Hyun Ha. Project administration: Jee Hyun Ha. Resources: Jee Hyun Ha, Jae Yong Jang. Supervision: Jee Hyun Ha. Validation: Jee Hyun Ha. Visualization: Jee Hyun Ha. Writing — original draft: Jae Yong Jang. Writing—review \& editing: Jee Hyun Ha.

\section{ORCID iD}

Jae Yong Jang https://orcid.org/0000-0002-2240-7683

Jee Hyun Ha ～https://orcid.org/0000-0002-0973-1139

\section{REFERENCES}

Arnett JJ, Taber S. Adolescence terminable and interminable: when does adolescence end?. J Youth Adolescence 1994;23:517-537.

Bernfeld S. Über eine typische Form der männlichen Pubertät. Imago 1923;9:169-188.

Bleiberg E. Normal and pathological narcissism in adolescence. Am J Psychother 1994;48:30-51.

Blos P. Prolonged adolescence: the formulation of a syndrome and its therapeutic implications. Am J Orthopsychiatry 1954;24:733-742.

Blos P. On adolescence: a psychoanalytic interpretation. New York: Free Press of Glencoe;1962. p.97-98, 186-191.

Blos P. The second individuation process of adolescence. Psychoanal Study Child 1967;22:162-186.

Blos P. The function of the ego ideal in adolescence. Psychoanal Study Child 1972;27:93-97.
Choi IH. The sqaure/the cloud dream of nine. Seoul: Moonji;2014. p.21202.

Colarusso CA. Child and adult development: a psychoanalytic introduction for clinicians. New York: Plenum Press;1992. p.91-105.

Elkind D. Egocentrism in adolescence. Child Dev 1967;38:1025-1034.

Erikson EH. The problem of ego identity. J Am Psychoanal Assoc 1956; 4:56-121.

Erikson EH. Identity and the life cycle. New York: W. W. Norton \& Company;1959. p.100-102.

Erikson EH. Childhood and society. 2nd ed. New York: W. W. Norton \& Company;1963. p.263-266.

Freud S. Formulations on the two principles of mental functioning. In: Freud A. The standard edition of the complete psychological works of Sigmund Freud. London: Hogarth Press;1911. p.218-226.

Gilmore KJ, Meersand P. The little book of child and adolescent development. Oxford: Oxford University Press;2015. p.203-248.

Ha JH. We are on the way of independence (Jigeum Dokriphaneun Jungipnida). Paju: Changbi;2017. p.13-17.

Jones E. Einige probleme des jugendlichen alters. Imago 1923;9:145168.

Kernberg OF. Factors in the psychoanalytic treatment of narcissistic personalities. J Am Psychoanal Assoc 1970;18:51-85.

Kernberg OF. Borderline conditions and pathological narcism. New York: Jason Aronson;1975. p.313-343.

Klein M. The psycho-analysis of children. London: Hogarth Press;1932. p.1-379.

Levinson DJ. The novice phase: the early adult transition, entering the adult world, and the age thirty transition. In: Levinson DJ, Darrow CN, Klein EB, Levinson MH, McKee B. Seasons of a man's life. New York: Ballantine Books;1978. p.71-90.

Martin J, Sokol B. Generalized others and imaginary audiences: a neoMeadian approach to adolescent egocentrism. New Ideas Psychol 2011;29:364-375

Tyson P, Tyson RL. Narcissism and superego development. J Am Psychoanal Assoc 1984;32:75-98. 